\title{
Oral Health in Brazil - Part I: Public Oral Health Policies
}

\begin{abstract}
Simone Rennó Junqueira(a) Cláudio Mendes Pannuti(b) Sigmar de Mello Rode ${ }^{(c)}$
\end{abstract}

(a) PhD, Professor, Department of Community Dentistry, School of Dentistry, University of São Paulo, São Paulo, Brazil.

(b) PhD, Professor, Discipline of Periodontics, School of Dentistry, Ibirapuera University, São Paulo, Brazil.

(c) PhD, Adjunct Professor, Department of Dental Materials and Prosthodontics, School of Dentistry of São José dos Campos, São Paulo State University, São José dos Campos, Brazil.

\begin{abstract}
This paper reviews the historical development of public health policies in Brazil and the insertion of oral health in this context. Since 1988, Brazil established a Unified National Health System ("Sistema Único de Saúde" - SUS), which was conceived to assure access to health actions and services, including oral health. However, a history of lack of access to health services and the health problems faced by the Brazilian population make the process of building and consolidating the SUS extremely challenging. Since 2004, the Oral Health National Policy has proposed a reorientation of the health care model, supported by an adaptation of the working system of Oral Health teams so that they include actions of health promotion, protection and recovery. Human resources should be prepared to act in this system. The qualifying process must take in consideration knowledge evolution, changes in the work process and changes in demographical and epidemiological aspects, according to a perspective of maintaining a balance between technique and social relevance.
\end{abstract}

Descriptors: Public health / history; Health policy; Oral health; Brazil.

\footnotetext{
Corresponding author:

Cláudio Mendes Pannuti

Faculdade de Odontologia

Universidade de São Paulo (FOUSP)

Departamento de Periodontia

Av. Prof. Lineu Prestes, 2227

Cid. Universitária

São Paulo - SP - Brasil

CEP: 05508-900

E-mail:pannuti@usp.br
} 


\section{Disclosures}

This article was sponsored by an educational grant from Johnson \& Johnson do Brasil Indústria e Comércio para Saúde Ltda.

\section{Introduction}

Over the last few decades, there have been great changes in the political, social and economic scenarios in Brazil. The nation restored democracy at the end of the 1980s after more than 20 years of military dictatorship, thus regaining the right to freedom of expression in matters concerning public policy guidelines, including in the health area.

The Human Development Index (HDI) in Brazil was 0.80 in 2005 , a result that, for the first time, placed Brazil among the nations with the highest human development indexes. ${ }^{1}$ Compared to the previous years, Brazil has advanced in three dimensions of the index: Longevity, income and education.

The indexes of inequality in income distribution have presented discrete reductions between 1990 and 2001, but in spite of falling, according to the World Bank, Brazil is one of the countries with the greatest social inequalities in Latin America and in the world.

In search for an explanation for social exclusion in Brazil, Pochmann, Amorim² (2003) have reported on its novel characteristics. According to these authors, social exclusion was initially marked by economic, political and social underdevelopment and by the genre of capitalism reproduced here, which was responsible for keeping a historically marginalized population distant from the fruits of economic growth. Thus, regions with broad exclusions marked by poverty, hunger, low income and low educational levels were created, which most frequently involved migrants, the illiterate, women, large families and the Afro-Brazilian population.

A new social exclusion has followed and may be explained by the increase of a significant part of the population that stands in a situation of social vulnerability. It affects social segments that were previously relatively preserved from the social exclusion process, such as young people with a high educational level, people older than 40 years of age, non Afro-Brazilian men and monoparental families. It is characterized by unemployment, informal work, urban violence explosion and by vulnerability of youth. ${ }^{3}$

Countries in Latin America, including Brazil, suffer from bad income distribution, illiteracy and low levels of education as well as precarious housing and environmental conditions, decisive factors in the population's life and health conditions.

The importance of the complexity of the healthillness process is the first step towards understanding that public policies, including oral health, must be directed to the well being of the population in general, guaranteeing the people's quality of life.

But for a country that has its roots profoundly anchored in a past of social exclusion and inequality of income distribution, there are still sectors that have to be developed and consolidated. In order to diminish social exclusion, access to essential goods and services, which directly impacts on the life quality of the population and, consequently, on the quality of public health, needs to be improved.

This paper reviews the historical development of public health policies in Brazil and the insertion of oral health in this context.

\section{The Brazilian health system}

Until the Constitution of the Republic was promulgated with the creation of the "Sistema Único de Saúde" - SUS (Unified National Health System), ${ }^{4}$ the health sector was historically organized in a dichotomic way: on one hand, a public health sector and, on the other, a social security assistance sector. ${ }^{5}$

The public health sector, connected to the Ministry of Health (MS) and the State (SES) and Municipal (SMS) Secretaries of Health were responsible for controlling endemics and epidemics and implementing vaccination actions and sanitary education with a repressive style of intervention at the individual and social levels. The social security assistance sector was responsible for providing ambulatory and hospital medical assistance only for formal workers and their dependents. ${ }^{6,7}$ When a citizen was registered in the formal job market, a monthly contribution to social security was deducted from his/her salary to assure the right to health care services, but only to this sector of the population. 
A movement known as the Sanitary Reform, based on popular battles against the military dictatorship and maintained by different social segments, sought to implement a unified national system of health in the country (no longer divided between public health and social security) and for all citizens (not restricted to formally employed workers).

This movement was also influenced by a global proposal of Health Promotion, conceived to go beyond the limits of the health sector and that calls for an articulation with other sectors and for a stimulus of social participation, as stated in the Declaration of Alma-Ata in 1978 and in the Ottawa Letter in 1986.

In Brazil, the $8^{\text {th }}$ National Health Conference (CNS) was held in 1986. It brought together organized civil society representatives, health care workers and managers of health services. On this occasion, a document was written "for the democratization of health care and society" with proposals for the organization of a health system according to the ideas of the Sanitary Reform.

During this period a National Constituent Assembly was being created and the representatives would be responsible for the creation of a New Constitution after the fall of the military regime. There was great political agreement among the members of the Assembly and the participants of the $8^{\text {th }} \mathrm{CNS}$ that the main deliberations of the Conference be accepted.

The new Constitution of the Republic ${ }^{4}$ acknowledged health as being a right of every person and a duty of the State, and it instituted the "Sistema Único de Saúde" - SUS (Unified National Health System). The SUS is not a service or institution but rather a system that comprehends a set of facilities, services and actions that interact with a common objective. It was designed to have the same organizational principles throughout the national territory.

The principles of this system, among others, are universalization, where access to actions and health services is guaranteed to each and every citizen; decentralization, where management has a sole command in each sphere of the government (federal, state and municipal) and the system is organized according to local needs (an important aspect since the national territory is vast and has great social, economic and epidemiological differences); integrality, because health services, in their diverse degrees of complexity, should develop actions of promoting, protecting and restoring health; participation of the community in the decisions related to health care by means of Health Advisors; and complementariness of the private sector, whether by contracting services when there is insufficiency of these by the public sector, or by allowing private enterprise to offer health services to the population.

After such a long history of lack of access to health services and given the health problems faced by the Brazilian population, characterized not only by the diseases prevalent in developed countries, but also by chronic-degenerative illnesses, one can imagine the extent of the challenge of building and consolidating the SUS.

\section{The Brazilian oral health system}

Implementation of public oral health care began in the decade of 1950 with the creation of the Dentistry Subsector connected to the "Serviço Especial de Saúde Pública” - SESP (Special Service of Public Health Care). It had been created in 1942 by means of an Agreement of Technical Cooperation between the governments of Brazil and The United States and maintained with the support of the Rockefeller Foundation. During the following decade, the SESP began to expand its action nationally, and was transformed into the Public Health Care Services Foundation (FSESP) connected to the Ministry of Health.

The two main actions taken at the time were: fluoridation of the public water supply, carried out experimentally in 1953 in the municipality of Baixo Guandu (in the state of Espírito Santo) and creation of a network of dental care in the form of the "Sistema Incremental" - SI (Incremental Dental Care Program). The SI was the first organized system of public oral health care. The aim of the SI was to provide dental care to a certain population (in the Brazilian case, school children from the first year of primary education), with the elimination of accumulated needs by means of curative procedures (vertical action) and posterior maintenance of health in 
the subsequent years with the use of fluorides (horizontal action). . $^{5,8}$

This model influenced all the initiatives of the government during the second half of the $\mathrm{XX}^{\text {th }}$ century, but the SI began to be reproduced uncritically, without an epidemiological focus, giving priority to curative actions that reduced the SI to a simple programmed technique in schools of the state public education network. ${ }^{7}$

Although a broad worldwide debate had begun emphasizing the economic and social determination of health since the 1960s, as opposed to the curative approach of disease control, the oral health practices in Brazil continued individualized.

Following the recommendations of the World Health Organization (WHO), the International Dentistry Federation (FDI), the International Association for Dental Research (IADR) and the international studies that had demonstrated the benefits of the addition of fluoride substances for caries control, the country finally adopted a technique of systemic public water supply fluoridation, making it obligatory since $1975 .{ }^{9}$

Public water supply fluoridation is the most effective action to promote oral health. Its epidemiological impact is an average $50 \%$ to $60 \%$ reduction in the prevalence of dental caries after 10 years of constant use. It was considered one of the ten greatest actions in public health in the $\mathrm{XX}^{\text {th }}$ century ${ }^{10}$ and almost 210 million people around the world benefited from it.

Epidemiological data have shown that the prevalence of caries was $49 \%$ higher in cities that did not use this systemic method. The missing and decayed components of the DMFT index were also significantly higher than those observed in the communities that received this benefit. ${ }^{11}$

However, until 2004, only $60 \%$ of the Brazilian municipalities with public water supply had implemented water fluoridation. Guaranteeing water fluoridation is a great victory, but guaranteeing adequate levels of fluoride content $(0.07 \mathrm{ppm})$ is also important to prevent the population from being exposed to an overdose, which could pose a risk of dental fluorosis, or to an underdose, which would not bring any benefit to the effort of reducing the prevalence of dental caries.

There are no doubts about the importance of public water supply fluoridation in the country, but, with the creation of the SUS in 1988, a need to define guidelines for oral health care emerged. Until that time, the practice of dental care was acknowledged as being inefficient, having low coverage, displaying a monopolistic and mercantile nature, having low resolution and being geographically and socially badly distributed. Dental care at schools was given priority, and the other citizens were offered only emergency care.

The "Política Nacional de Saúde Bucal" - PNSB (Oral Health National Policy) was created in 1989. It stated that the dental care system should be structured to offer primary care services to all of the population according to the principles of the SUS. Thus, oral health teams should remain in Health Care facilities, and no longer in schools. A severe epidemiological situation was acknowledged in Brazilian oral health, mainly as regards dental caries in childhood (Graph 1).

Therefore, priority was given to actions in the age group from 6 to 12 years because of the eruption of permanent teeth and because of the efficiency of educational attitudes and topical preventives at this stage.

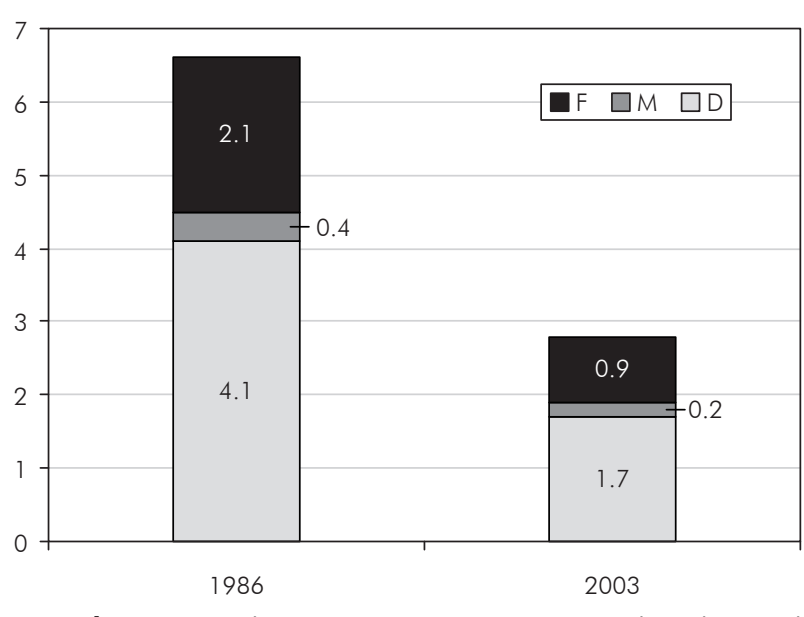

Graph 1 - Dental caries experience. DMFT index [decayed (D), missing (M) and filled (F) teeth] among 12-year old children. Brazil, 1986 and 2003. Sources: Brasil. Ministério da Saúde. Levantamento epidemiológico em saúde bucal: Brasil, zona urbana, 1986.14 and Brasil. Ministério da Saúde. Projeto SB Brasil 2003."1 
However, this model, by giving priority to specific groups, frequently excluded those that did not belong to them, and this offended the constitutional right to equal and universal access of the entire population to health services. ${ }^{12}$

Although edentulism is usually not considered a public health problem, it should be pointed out that it is caused by caries and/or periodontal disease, principally in adults and elderly people. In a great number of countries in the world, dental loss is still considered a natural consequence of aging. The United States have $26 \%$ of edentulous individuals in the group from 65 to 69 years of age and some countries in Europe, such as Italy, Austria and Lithuania, have less than $20 \%$ of completely edentulous individuals between 65 and 74 years of age. ${ }^{13}$

In $1986,40 \%$ of adults and $72 \%$ of elderly Brazilians were edentulous. ${ }^{14}$ Seventeen years later, the preliminary results of the World Health Research conducted in Brazil by the Ministry of Health and Oswaldo Cruz Foundation (FIOCRUZ) ${ }^{15}$ pointed to a percentage of $37.8 \%$ of individuals over 50 years of age without a single natural tooth present in the mouth.

For adolescents, adults and elderly people the situation is still very distant from an optimal oral health status. This also happens in developed countries, because the practice of dental care adopted by the majority of countries gives priority to curative treatment, mainly in children, to the detriment of actions of a collective nature with the goal of health promotion. This practice has shown to be inefficient for improving oral health and the situation for adults is still precarious all over the world.

In subsequent governments, few actions were adopted with the intention of improving the oral health condition of the population. Creation of the "collective procedures" in 1991 stands out as it made the municipalities plan actions, collective in scope, which were complementary to the curative individual actions. They involved supervised brushing with the distribution of toothbrushes, dentifrices and topical fluoride application after epidemiological survey, performed weekly by an oral health team in previously determined locations. In general, these actions were performed in primary schools.
A new perspective in planning oral health actions in the public sector was adopted in 2000, with the inclusion of oral health teams in the "Programa de Saúde da Família” - PSF (Family Health Program) that was created in 1994. This program was developed as a strategy to restructure the model of primary care of the SUS. The fundamental basis of its action is territorialization, with a focus on determining the social and epidemiological needs of a given population and overseeing the application of health actions. It also aimed at ensuring proper integration with the other levels (secondary and tertiary) of health care by the SUS. Therefore, it should not be analyzed as an isolated and vertical process of the Brazilian public health structure. ${ }^{16}$

In this context, oral health must also have a structured focus on the concept of health promotion that is integrated with the other health areas.

People normally seek health services when they notice some illness which, according to Moysés et al. ${ }^{12}$ (2008), generates a mistaken model of practice, based on care giving to a self-referred complaint, and results in protracted procedures and few resolutions.

Furthermore, according to the authors, the intention of the PSF is to break these dental practices that have been rooted in the day-to-day activities of health facilities for centuries, by instituting principles that may guide health teams in establishing territories for priority care, in controlling oral illnesses and in focusing on their epidemiological impact in the medium and long terms. Families have been receiving health professional home visits with the purpose of giving guidance and following up the health-illness process in the family circle.

The Ministry of Health has provided the municipalities with financial incentive to create PSF teams, including an oral health team (composed of a dentist and an assistant) and this has contributed to an increase in the number of professionals involved and in the number of people covered by the program (Graph 2).

At the beginning of 2004, the Ministry of Health released a new Oral Health National Policy ${ }^{17,18}$ integrated to the "Plano Nacional de Saúde: um pacto pela saúde no Brasil” (National Health Plan: a 


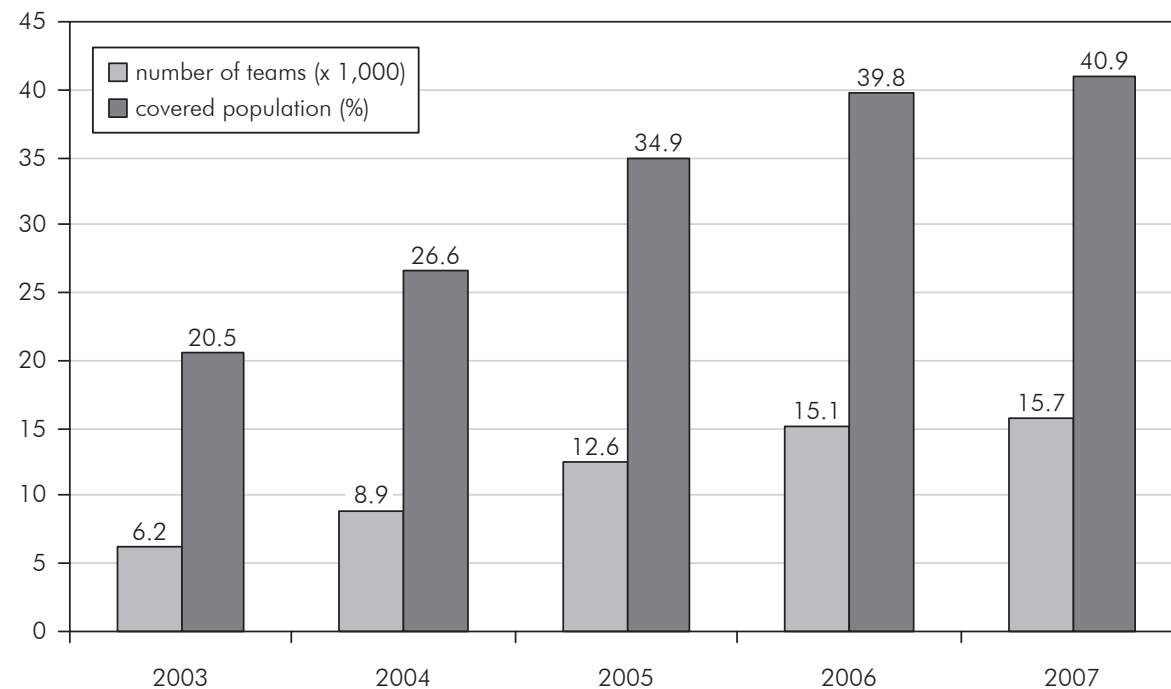

Graph 2 - Number of oral health teams in the Family Health Program $(x 1,000)$ and covered population (\%). Brazil, 2003-2007. health covenant in Brazil) that emphasizes the need to increase access to oral health care.

To this end, with an integral view of the healthillness process, the PNSB proposes a reorientation of the health care model, supported by an adaptation of the working system of Oral Health teams so that they include actions of health promotion, protection and recovery. The intention is to rationally increase access to integrated oral health care, where "care lines" (since childhood through adolescence, adulthood and old age) may have a centralized flow that includes the stages of welcoming, information giving, attendance and referral (including referral and contra-referral), in order to result into resolution actions. ${ }^{19}$

In order for this change in dental care practice to occur, important processes are necessary to increase and qualify assistance to guarantee access to primary care, and also to improve the structure of secondary and tertiary care. These specialized dental services, in the SUS circle, correspond to no more than $3.5 \%$ of total dental clinical procedures. ${ }^{17}$

Among the actions included in the policy and financed by the Ministry of Health are:

a. Implementation of the "Centros de Especialidades Odontológicas” (CEO) (Dental Specialties Centers). These centers have been distributed in all the municipalities of the Brazilian states with a history of reference in specialized health care in other areas. In the CEOs, clinical procedures complementary to primary care procedures include periodontal surgery, endodontic treatment, minor oral surgeries, diagnosis and support for the treatment of oral lesions, and treatment provided to special patient groups;

b. Distribution of products to oral health teams to perform restorative and preventive clinical procedures that increase the resolution of primary care procedures;

c. Increased incentives to PSF oral health teams by supplying more modern dental equipment;

d. Financial support for the implementation of fluoridation of the public water supply in the municipalities that have not yet implemented this procedure. ${ }^{17,18}$

This policy also includes a permanent epidemiological and information vigilance system that follows up the impact of actions, assesses and plans distinct strategies and/or adaptations that are needed according to the different socioeconomic profiles of the Brazilian population. Thus, an agenda of scientific research that involves the study of the main oral health problems and the development of technological alternatives to address them is a fundamental part of this policy and has been encouraged.

In order to effectively implement these actions in the medium to long terms, follow-up by and effective participation of the society are necessary. This process is made possible in the day-to-day activities 
of the SUS by means of Municipal and State Health Counseling existent throughout the national territory, as well as by the participation in Health Conferences convened for permanent dialogue and debate of the participants involved in building a system that is dynamic and democratic.

\section{Human resources}

It is necessary to qualify dentists to be able to plan, execute and assess individual and collective actions directed towards the socioeconomic as well as the epidemiological needs of the population, whether to work in the private or in the public sector.

In 2005, there were more than 45 thousand health establishments in the SUS and, among these, $60 \%$ offered dental services. ${ }^{20}$

In 2008, Brazil will exceed 187 million inhabitants. Data from the "Conselho Federal de Odontologia” - CFO (Federal Dentistry Council), updated in May 2008, registered 219.702 dentists throughout the national territory graduated from more than 185 Dentistry Colleges. The proportion is 1 dentist to 851 inhabitants. As regards assistants, there are fewer than 70 thousand that work in the country. ${ }^{21}$

To adopt the need for increasing the number of dentists in the labor market as a criterion, based on the assumption that there are many people that do not have access to oral health services due to lack of professionals, did not and will not suffice to revert the oral health epidemiological situation in Brazil.

As regards access to dental services, the report from the Brazilian SB Project 2003 has affirmed that $13.5 \%$ of the Brazilian population has never been to a dentist. ${ }^{11}$

It is known that, in addition to a quantitative unbalance, the country suffers from an irregular distribution of professionals. In order to plan this distribution, social and epidemiological criteria must be adopted. In the State of São Paulo, for example, the number of dentists registered at the Regional Dentistry Council is higher in municipalities that present the best social indicators such as average income, index of life conditions and income distribution, which denotes the preferential private nature of professionals. ${ }^{22}$

The present guidelines of the National Council of Education, expressed in the national curricula directives for Dentistry Courses, reinforce the importance of educating dentists to "act on all the levels of health care (...) based on ethical and legal principles, as well as to understand the social, cultural and economic realities in their environment, and to direct their activities towards transforming these realities to the benefit of society". ${ }^{23}$

Even though an education for health professionals must include traditional tasks of a technical nature, it is necessary for them to understand that working in health care means acquiring knowledge and skills for interlocution, addressing a public and principally incorporating the political universe that surrounds them in this exercise.

The best qualification of future professionals must be accompanied by education and integration of other professionals in the Oral Health Team, such as dental office assistants and dental hygienists. According to Narvai ${ }^{24}$ (2003), "the oral health team is the new subject of a new dental practice seeking to create and consolidate a practice that is effectively capable of promoting oral health". Rational integration of these professionals allows an increase in productivity, quality and income of the work system, provided that an adequate proportion between assistants and dentists is observed.

The educational process must consider the accelerated rhythm of the development of knowledge, the changes required in the work process, and the transformations in demographic and epidemiologic aspects, following a perspective of balancing technical excellence and social relevance. ${ }^{25}$

Thus, at the end of 2005, the "Programa Nacional de Reorientação da Formação Profissional em Saúde - Pró-Saúde" (National Program for the Reorientation of Professional Education in Health - Pro-Health) was created with the technical and financial support of the Ministry of Health and the Pan-American Health Organization so that higher education courses in Dentistry could undergo a process of curricular change. It is hoped that this reorientation in the professional education process will promote a teaching / service providing integration that may assure an integral approach to the healthillness process as its central axis. ${ }^{25,26}$ 


\section{Research and publication in oral health}

One problem in research and publication in health sciences is the concentration of financial, scientific and technological resources in the hands of few countries of the North Hemisphere. Nowadays, Brazil is considered one of the Innovative Developing Countries (IDC). ${ }^{27,28}$

Between 1985 and 2004, the number of published scientific articles increased 12-fold in Brazil. The total number of epidemiological articles indexed in MEDLINE/PubMed and Institute for Scientific Information/Thomson Scientific - ISI more than doubled. ${ }^{29}$ Zorzetto et al. ${ }^{30}$ (2006) observed a substantial increase in the scientific production in health and biological sciences in the 20 most productive Brazilian universities, which are responsible for $78.7 \%$ of the papers in these areas.

Evolution of the Brazilian production in public health research can be observed when considering the number of studies presented in the Dental Research for Communital Action category ("Pesquisa Odontológica de Ação Coletiva - POAC)" at the Annual Meeting of the "Sociedade Brasileira de Pesquisa Odontológica” - SBPqO) (Brazilian Society for Dental Research), the Brazilian Division of the International Association for Dental Research - IADR (Graph 3). Another issue to be considered in the quality of research is the evolution of Bioethics and its impact on policy and procedure of the research/ publication process involving human beings. ${ }^{31,32}$

\section{Final considerations}

Health care in Brazil must be thought of within the social and economic context in which the country lives, which is characterized by social inequality and a high rate of unemployment. In order to address the pressures of accelerated urbanization, an aging population, increase in the rate of illnesses typical of underdevelopment, among others, a combination of acceptable employment conditions, security, basic education, adequate diet, availability of water, sewerage, waste disposal services and better environment conditions are required, with an emphasis on the prevention of diseases and promotion of the quality of life of the population.

In view of the Brazilian social and epidemiological situation and the importance of determinant factors in the health-illness process, public policies must be directed to health promotion, with strategies emphasizing the creation of conditions favorable to the development of health and the qualification of health care professionals.

Change in behavior or habit is only one of the objectives of health education. The purpose of education is human freedom, that is to say, propitiating that individuals be the subjects of their own learning and true participants in the educational activities so as to develop a critical thinking capable of analyzing the social context of their problems in order to seek solutions.

Thus, it is necessary first to educate socially committed professionals capable of producing changes,

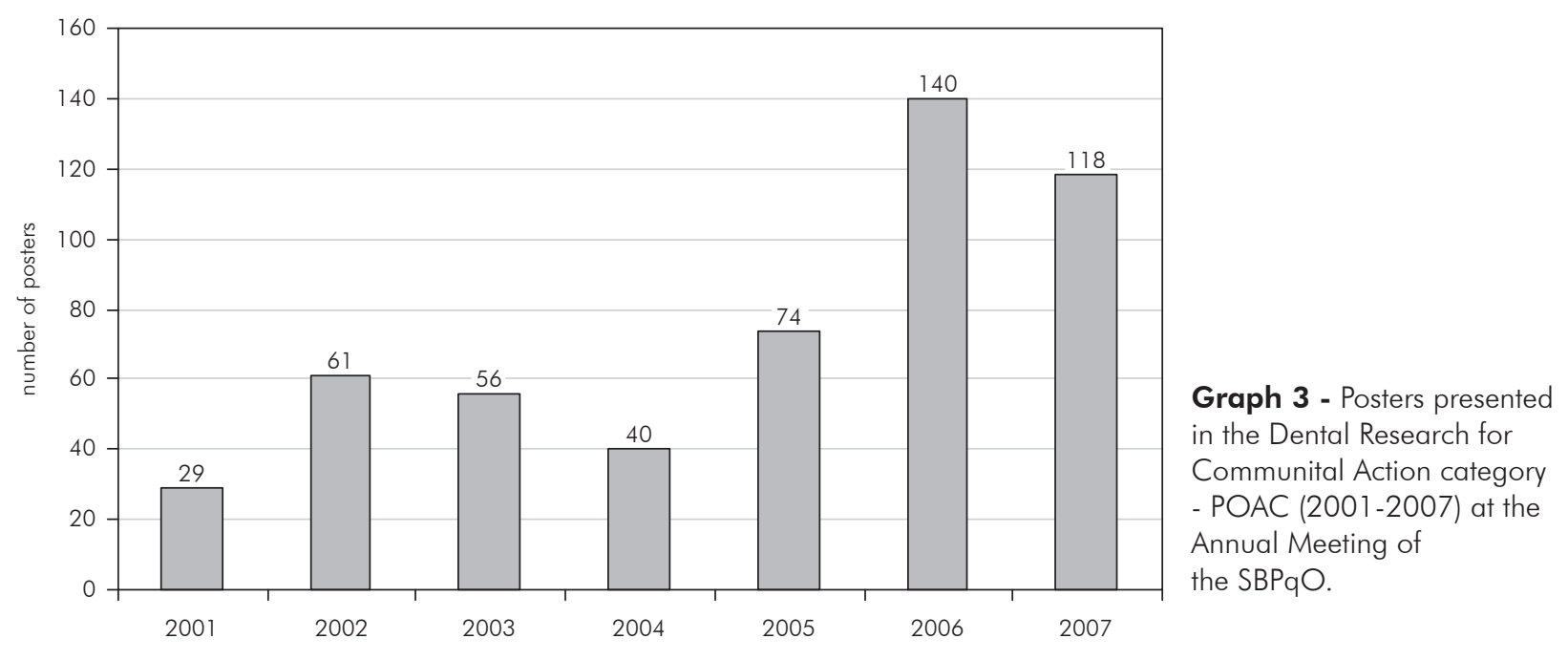


not only in the illness pattern of the population, but fundamentally creating awareness of the importance of the population's participation in planning, executing and controlling the actions and services provided to the community.

The knowledge held by the organized civil society about the oral health needs and the limitations of the system (that still exist) will only favor the development of public policies that are suited to the epidemiological profile and improve the oral health quality of the population.

As regards the health needs of the population, strategies adopted at the communital level, such as water supply fluoridation, addition of fluoride to dentrifices and structuring communital actions within the scope of the SUS have contributed to decrease the dental caries indexes in children (Graph 1). Nevertheless, formulating a broader national oral health policy is required to meet the needs of the entire Brazilian population from all age groups. Policy

\section{References}

1. PNUD. Programa das Nações Unidas para o Desenvolvimento. Relatório do desenvolvimento humano 2007/2008. Combater as alterações climáticas: Solidariedade humana num mundo dividido. Coimbra: Edições Almedina; 2008.

2. Pochmann M, Amorim R (orgs.). Atlas da exclusão social no Brasil. 2a ed. São Paulo: Cortez; 2003.

3. Campos A, Pochmann R, Amorim R, Silva R (orgs.). Atlas da exclusão social no Brasil: dinâmica e manifestação territorial. vol. 2. São Paulo: Cortez; 2003.

4. Brasil. Constituição (1988). Constituição da República Federativa do Brasil. Brasília, DF: Senado; 1988.

5. Abreu MHNG, Werneck MAF. Sistema incremental no Brasil: uma avaliação histórica. Arq Odontol. 1998;34(2):121-31.

6. Paulus AJ, Cordoni LJ. Políticas públicas de saúde no Brasil. Espaç Saúde. 2006;8(1):13-9.

7. Narvai PC, Frazão P. Políticas de saúde bucal no Brasil. In: Moysés ST, Kriger L, Moysés SJ (coords.). Saúde bucal das famílias: trabalhando com evidências. São Paulo: Artes Médicas; 2008. p. 1-20.

8. Narvai PC. Odontologia e saúde bucal coletiva. 2a ed. São Paulo: Santos; 2002.

9. Bleicher L, Frota FHS. Fluoretação da água: uma questão de política pública - o caso do Estado do Ceará. Ciênc saúde coletiva. 2006;11(1):71-8.

10. CDC. Centers for Disease Control and Prevention. Achievements in public health, 1990-1999: fluoridation of drinking must no longer be characterized by addressing only the "future generations" and by mutilating the adult population.

Brazilian Public Oral Health has entered the $\mathrm{XXI}^{\text {st }}$ century with important challenges, such as to universalize assistance and information in order to alter the epidemiological profile of the adult population; to implement a rational work system by means of oral health teams; and to increase access of the Brazilian population according to a holistic perspective of health that takes into account the profile of each population and at the same time promotes equality.

Maturation and consolidation of Public Oral Health in Brazil has shown that building a model, previously believed to be utopian, is feasible and will eventually culminate in a broader Oral Health National Policy. As with all processes, this "health consciousness" does not come into being overnight, but one can say that it is in full development.

water to prevent dental caries. MMWE Morb Mortal Wkly Rep. 1999;48:933-40.

11. Brasil. Ministério da Saúde. Secretaria de Atenção à Saúde. Departamento de Atenção Básica. Projeto SB Brasil 2003: condições de saúde bucal da população brasileira 2002-2003. Resultados principais. Brasília: Ministério da Saúde; 2004.

12. Moysés SJ, Nascimento AC, Gabardo MCL, Ditterich R. Apontamentos para estudos e debates sobre a Estratégia Saúde da Família. In: Moysés ST, Kriger L, Moysés SJ (coords.). Saúde bucal das famílias: trabalhando com evidências. São Paulo: Artes Médicas; 2008. p. 47-64.

13. World Health Organization. The World Oral Health Report, 2003. Continuous improvement of oral health in the $21^{\text {st }}$ century: the approach of the WHO Global Oral Health Programme. Geneva: WHO/NMH/NPH/ORH; 2003.

14. Brasil. Ministério da Saúde. Secretaria Nacional de Programas Especiais de Saúde. Divisão Nacional de Saúde Bucal. Levantamento epidemiológico em saúde bucal: Brasil, zona urbana, 1986. Brasília: CD-MS; 1989.

15. Brasil. Ministério da Saúde. Fundação Oswaldo Cruz. Pesquisa Mundial de Saúde. Brasil 2003. Primeiros Resultados. Rio de Janeiro: Fiocruz; 2003.

16. Roncalli AG. O desenvolvimento das políticas de saúde no Brasil e a construção do Sistema Único de Saúde. In: Pereira AC. Odontologia em Saúde Coletiva: planejando ações e promovendo saúde. Porto Alegre: ArtMed; 2003. p. 28-49. 
17. Brasil. Ministério da Saúde. Diretrizes da Política Nacional de Saúde Bucal [acesso 21 set 2004]. Disponível em: http://www. saude.gov.br.

18. Brasil. Ministério da Saúde. Programas da Saúde. Brasil Sorridente [acesso 21 set 2004]. Disponível em: http://saude.gov.br.

19. Junqueira SR, Frias AC, Zilbovicius C. Saúde bucal coletiva: quadros social, epidemiológico e político. In: Rode SM, Gentil SN. Atualização em Odontologia. São Paulo: Artes Médicas; 2004. p. 591-604.

20. Brasil. IBGE. Instituto Brasileiro de Geografia e Estatística. Assistência Médica Sanitária 2005. Malha municipal digital do Brasil: situação em 2005. Rio de Janeiro: IBGE; 2006. Disponível em: http://www.ibge.gov.br/estadosat/index.php.

21. CFO. Conselho Federal de Odontologia. Dados do CFO. Disponível em: http://www.cfo.org.br/index.htm.

22. Junqueira SR, Araujo ME, Antunes JLF, Narvai PC. Indicadores socioeconômicos e recursos odontológicos em municípios do Estado de São Paulo, Brasil, no final do século XX. Epidemiol Serv Saúde. 2006;15:41-53.

23. Brasil. Conselho Nacional de Educação. Câmara de Educação Superior. Resolução CNE/CES no 3, de 19/02/2002. Brasília: DOU; 04/03/2002. Seção 1, p. 10.

24. Narvai PC. Recursos humanos para promoção da saúde bucal: um olhar no início do século XXI. In: Kriger L. Promoção de saúde bucal: paradigma, ciência, humanização. $3^{\text {a }}$ ed. São Paulo: Artes Médicas; 2003. p. 475-94.
25. Brasil. Ministério da Saúde. Ministério da Educação. Programa Nacional de Reorientação da Formação Profissional em Saúde - Pró-Saúde: objetivos, implementação e desenvolvimento potencial. Brasília: Ministério da Saúde; 2007.

26. Araujo ME, Zilbovicius C. A formação acadêmica para o trabalho no Sistema Único de Saúde (SUS). In: Moysés ST, Kriger L, Moysés SJ (coords.). Saúde bucal das famílias: trabalhando com evidências. São Paulo: Artes Médicas; 2008. p. 277-90.

27. King D. The scientific impact of nations. Nature. 2004;430:3116.

28. Paraje G, Sadana R, Karam G. Public health. Increasing international gaps in health-related publications. Science. 2005;308:959-60.

29. Barreto ML. Crescimento e tendência da produção científica em epidemiologia no Brasil. Rev Saúde Pública. 2006;40(N Esp):79-85.

30. Zorzetto R, Razzouk D, Dubugras MT, Gerolin J, Schor N, Guimarães JA et al. The scientific production in health and biological sciences of the top 20 Brazilian universities. Braz J Med Biol Res. 2006;39(12):1513-20.

31. Gollogly L, Momem H. Ethical dilemmas in scientific publications: pitfalls and solutions for editors. Rev Saúde Pública. 2006;40(Spec N):24-9.

32. Junqueira CR, Rode SM. Ética na odontologia. Petrópolis: Vozes; 2007. 